\title{
Higher Education in Prison Contexts: The Prison Situation as Limit Experience
}

\author{
Mónica Díaz Pontones ${ }^{1, *}$, Miguel Monroy Farías ${ }^{2}$ \\ ${ }^{1}$ Higher Education Program for Social Readaptation Centers (PESCER), Autonomous University of Mexico City (UACM), Mexico \\ ${ }^{2}$ School of Higher Studies Iztacala, National Autonomous University of Mexico, Mexico
}

Copyright $\bigcirc 2018$ by authors, all rights reserved. Authors agree that this article remains permanently open access under the terms of the Creative Commons Attribution License 4.0 International License

\begin{abstract}
The prison experience is not exclusive to those, for whom the State has removed their freedom. According to Heidegger, humans can live in a prison for our entire existence. The family of origin, the one you build, school, among others, may be true prisons from which it is incredibly difficult to separate. However, the actual experience of being enclosed by walls has peculiar qualities; therefore, the central concern of this research work is on the limit situation occurred within prison and the return home from it. One can say that certain events that occur inside the prison come to be, for some inmates, a limit situation. However, one must ask: What kinds of events are we talking about? What is it that occurs and how do these events reveal a threshold, a limit? How is this type of situation made to happen through speech? And how do you return home after a limit situation? Moreover, we assume that the return home is not merely a biographical accident, we do not only speak of the customs and 'prison practices' learned during confinement or of the punishment, penalties or multiple activities, tasks and encounters the newly freed have to undertake on their return. Above all, it tells us about the suffering that comes from failing to reach what is desired; of those appropriator events that occurred during imprisonment, those certain processes of subjectivation that have to do with the relationship that is established with oneself and with others, with the different and complex ways of relating and becoming a subject of one's own existence; it tells us of the 'vision of oneself' and notices how the 'narrative identity' is formed through the 'given speech'.
\end{abstract}

Keywords Limit Situation, Return Home, Prison Experience, Anguish, Death, Being and Higher Education in Correctional Settings

We are not truly free, Heidegger highlights repeatedly, instead we are enclosed in a prison we carry with us all our lives. The desire to free us from this prison is behind his [Heidegger's] life's work [1].

\section{Introduction}

Posing of the Research Question. The prison experience is not exclusive to those, for whom the State has removed their freedom. According to Heidegger as quoted by Petzet in the epigraph, humans can live in a prison for our entire existence. The family of origin, the one you build, school, among others, may be true prisons from which it is incredibly difficult to separate. However, the actual experience of being enclosed by walls has peculiar qualities; therefore, the central concern of this research work is on the limit situation occurred within prison and the return home from it.

It can be said that certain events that occur within the confinement can be configured for some inmates in a borderline experience. From the Heideggerian perspective, the limit experience is understood as the possibility to experience the Being (Sein) in light of the event (Ereignis). "Recognition of the importance of limit experiences comes from Heidegger's own life. Heidegger narrates a limit experience in the letter to MedardBoss dated August 2, $1952,[\ldots]$ he put death before him and it allowed him to take a look at everything and nothing. That experience, which is called Abituriententraum (dream of the high school graduation exam), had a single scene: Heidegger was in the Gymnasium and was sitting his final exam-the Abiturientenprüfung - before a group of professors - the same ones who were present when he took that same exam as a young man"[2].

However, it is necessary to ask what kind of events are we talking about? What is happening and how is it that these events reveal a threshold, a limit? How is that type of experience made to occur through the word? How do you return home from a limit experience?

But, why does the specific incarceration experience establish conditions favorable to bringing about these types of events? Let us remember that "Existence does not give 
the being its meaning, it is existence that receives its meaning from the being, and by meaning we understand patency (Erschlossenheit) of the being and not just the entity itself"[3].

And, how is it that those events allow some inmates to appropriate something that makes it so that that something "is clearly in its place"? ${ }^{1}$ [4]? Thus, comprising a limit experience: an experience that we do not make, but rather makes us be, as Nancy states [5].

The most important antecedent for this study was the creation of the Higher Education Program for Social Readaptation Centers in the Federal District "PESCER" of the Autonomous University of Mexico City. The initiative to offer university studies in all detention centers of the D.F. arose from the rector of the University and the authorities of the General Directorate of Prevention and Social Readaptation of the Federal District (DGPRS). Thus, in December 2004, the UACM and the DGPRS signed a collaboration agreement with the purpose of providing programs of higher education, research, dissemination of culture and university extension to internal people wishing to initiate, continue or conclude their higher level studies. To this end, appropriate programs were structured to such circumstances, in order to facilitate the incorporation of as many students as possible of interested.

In April 2005, classes began at the facilities of the Women's Social Readaptation Center and the Santa Martha Acatitla Men's Penitentiary, offering three degrees: Law, Political Science and Urban Administration and Literary Creation. The central purpose of the program is to promote educational processes in order to reverse the situation of isolation and marginalization of the prison population. These educational formative processes are based on respect for diversity and on the promotion of democratic forms of life. By rescuing the value of the public in its broadest sense, the UACM "creates new training spaces in which, with the independence of the social or economic singularity, it gives value to the person, to the human being, to his capacity to grow and to learn encouraging freedom of thought and decision-making responsibility"[6].

In Mexico there are few experiences on campus university training in prison, so the initiative of the UACM opens in the Federal District (now Mexico City) an educational opportunity that will not only benefit the inmates but also the authorities penitentiaries. For the UACM, public education, in its broadest conception, seeks to integrate the largest number of aspirants regardless of their social or economic situation. "A public education institution, thus defined, is one where the differences that accentuate inequality are eliminated. In this sense, and with the purpose of offering support to one of the marginal

\footnotetext{
1 That something which makes that that something "is clearly in its place," is, in Heidegger's terms, the "Ereignis: occurrence" or "opportune event" that makes that something "be clearly in its place" as Félix Duque proposes. Cfr. His introduction to Pöggeler 1983: 47" [4].
}

sectors of society, the University has taken its educational model to the interior of the Rehabilitation Centers of the Federal District, structuring flexible programs with the purpose of incorporating the greatest number of interested persons and to reduce the exclusion caused by rigid institutional programs "[7].

One of the first problems faced by the Program is that the penitentiary system as a whole, conceives of education as a measure of social reintegration, which is why it is "taken and used" as part of the therapeutic action indicated to "cure internal and internal": similarly, training activities are understood as strategies to accumulate benefits or as means of exchange ${ }^{2}$ [8]. Education, it is not thought of and less assumed, as a human right $^{3}$ [9] as "a social opportunity for both the present and the future, which and allow the person incarcerated to develop profitable educational trajectories, specifying the human right to the project of life ... "[10].

Guiding Questions. It can be said that certain events that occur while imprisoned, come to constitute, for some inmates, a limit experience. However, it is necessary to ask, what kind of events are we talking about? What is it that occurs and how is it that these events reveal a threshold, a limit? How is this type of experience made to happen through speech? And how does one return home after a limit experience?

The prevailing conditions inside most prisons in Mexico and particularly in Mexico City are deplorable, afflictive, hopeless, and cruel for the vast majority of those who are forced to live within their walls and wire fencing. Nevertheless, there are certain peculiarities of that exact incarceration experience that serve as "humus"[11], providing certain events that become appropriator events which make up a limit experience. Such particularities are incorporated in the specific incarceration experience in prisons in Mexico City.

Two questions stand out in the research paper guide: does forced imprisonment always give rise to a limit experience? And, how does one return home, in regards to the limit experience, when forced confinement has made it possible to "experience the Being (Sein) in light of the occurrence (Ereignis)"? [12].

\section{Objectives}

Document how certain opportune events can come to constitute a limit experience. Explore the return home as an im-possible. Analyze the variety of meanings that higher education can take on in the context of confinement or parole.

2 See Goffman, systems of punishments and privileges as modes of organization of total institutions. [8]

3 See, for example, the Recommendations of the Latin American Campaign for the Right to Education. [9] 


\section{The Research}

\section{Theoretical Perspective}

Hermeneutic phenomenology ${ }^{4}$ is the theoretical perspective of this paper. From a Heideggerian vision, the interest is in the sense of the being in understanding what the everyday implies and the fall as habitual forms Dasein is found in the world and how $<<$ foreseeing of death $>>$ constitutes one of the ways of recovering, in an educational form:

"[...] Dasein is born in the everyday, in the "world of oneself"*, it cannot help by appear as part of that world, lost in it, and thus, at first is governed by idle talk, eagerness for novelty, and ambiguity" [13].

Addressing the return home from a limit experience implied a new way of approaching that return. Indirect routes were laid for grasping that which is hidden or disfigured, that which is not immediately and regularly apparent, that which appears only to be covered up again, as Heidegger himself says:

"But that which an indicated meaning remains hidden or becomes covered up again or is only shown "vaguely," is not such or such entity, rather [...] the being of the entities. Inasmuch as it can be covered up it is forgotten, and neither it nor its meaning is asked about" [14].

Such research required, in the first place, a change in the way of looking, a turn to understand, among other things, how death has been conceptualized; how it has moved from "familiar, domesticated death" to the "uninhibited, wretched [death that is] banned from our days," as stated by Ariès [15]. But changing our way of seeing was not a simple question. It required thinking contrary to oneself ${ }^{5}$ [16], undertaking a way toward ${ }^{6}[17]$, interrogating existence, not as existence in the usual meaning of the word, but as "[...] that emergence of the being that man discovers prior to any definition of himself [...]" [18]. And it was precisely this interrogation, this urgent need to ask after the being, this demanding to understand that the being is a "[...] phenomenon of lived experience, something that appears and shows itself to itself" [19], which offered an opening, an opportunity, a possibility: understanding imprisonment as a limit experience and what occurs when one returns home.

Limit experiences imply a transformation, a change, one is not the same after having lived through an event that

\footnotetext{
4 Or hermeneutics of facticity.

5 Alluding to one of the three dangers that threaten thought according to Heidegger. "[...] What is bad and severe is thought itself, he must think against himself and he rarely manages to do it" [16].

6 "Question widely deployed in Arturo Leyte's introduction to Heidegger (2005), and in Rüdiger Safranski's monograph Heidegger y el comenzar' [17].
}

makes "something be in its place," which gives rise to understanding something as fundamental as our finitude [20] and thus, the emergence of our possibilities, or in Heidegger's terms, "inherited tradition".

Limit experience, "limit situation", "liminary experience," "liminary phase or rite of passage," "peak experience" are all just ways of referring to an opening that reveals the ineffability of being. All are ways of talking about un-covering, pain and suffering, dissolution of the individual, the habitual, the everyday, the familiar, safety, established orders and assigned roles. All are forms that reveal the problem of the truth, the problem of the self and the problem of temporality.

On the other hand, we approach the return home, that unattainable desire to return, which the interview subjects call "the thing that gives you security," or, in other words, origins. But returning to one's own or origins implies having gone "[...] through the strange (das Fremde) that questions us"[21], that envelops "[...] suffering caused by a specific event: not being able to return"[22], and thus, the return is impossible, as in order to exist one must be in a constant state of departure, as Nancy states ${ }^{8}[23]$.

We know that returning is impossible but even still, it sets in like a persistent struggle to attain the unattainable, to feel that security once again, that familiarity, to once again inhabit a territory that was thought to be one's own where objects and subjects were recognizable as static, definable, and independent of us:

"[...] our perception of things depends on us and our belief that they are static and definable is a result of an event we carried out at the dawn of humanity: abandoning the world of things and substituting it with one of words" [24].

Investigating the limit experience and the return home from it obliged us to dialogue with students from other places and other contexts.

The new theoretical questions that broke into this investigative adventure, forced us to have to "think" from other places, from other perspectives, with other references from which the emanated another type of dialogue with the students in a situation of imprisonment and with their narratives. With respect to breaking with the fundamental models and the ways of perceiving the events, it is mandatory to point out that, in the first place, it was necessary to ask ourselves, if it were possible to say a limit experience, understood as an event. For this, we refer to what Derrida raises in his article entitled Certain possibility impossible to describe the event, where it is convenient "[...] to remember that an event entails surprise, being exposed, the unacceptable" [25], where the impossibility of saying the event obliges us as says Derrida to think

7 The finitude is not a mere property, "[...] rather it is the fundamental mode of our being" [20].

8 For this author, the identifying feature of modern exile is always the return: "[...] exile is only transitory" [23]. 
differently.

Methodology Employed. Qualitative research. Case studies. The change of student representations upon an encounter with the being after a limit experience had repercussions in several dimensions. Among them, in regards to methodology, selecting and forming the group of research participants. Once again, the questions were posed: what individuals would we be able to work with? At which prisons could the fieldwork be conducted? And, what type of questions will be posed in order to "set off" certain conversations? In order to transcend certain limits, to access something deeper inside, something that pre-says [26], that tells the origin, that goes inside that, that which occurred, that which irrupted inside prison or that which is revealed at the return home.

The methodologies used in this research work respond to the principles and suspects of the Qualitative-Interpretative research, the Unique Case Study and the Phenomenology. These principles guided not only the description but also the interpretation of an object of study under construction whose character is unique, unrepeatable, and peculiar and to some extent difficult to access: higher education in reclusion contexts and the prison situation as a borderline experience.

The object of study was the product of a constant process of construction, and critical reflexivity ${ }^{9}$ [27], where the observations, the in-depth interviews, the "informal" talks, the prolonged stay in the "field", the conceptual referents, the ways of seeing -to be-and-perceive the world, the ethnographic analysis and the periodic reformulation of the guide-questions were giving rise to this object of study. Object that is only "perceived and understood through an internal organization of the data, mediated by conceptual constructs and ways of seeing the world" as Willis affirms [28] and that is manufactured, according to Geertz [29] to participate and to give account of some particularities of what we call reality.

The object of study was "materializing" in different analysis schemes, which we call matrices because of their possibilities of ordering multiple "concepts" that interact with each other within a structure. These "concepts" came off at the beginning of the research design phase, of the guide questions, of the first approaches with the university students and of the theoretical contributions; later, they were fed with the observations, the records of the field journals, with the transcriptions of the in-depth interviews and the dialogues (field work), with the analysis and with the codification.

We built different matrices of analysis through which we

9 The principle of reflexivity in research is central, postulates that descriptions relating to some aspect of the social world are simultaneously within the same world that is described (are part of it). "As a result, there is no place for the social world simply to describe something. Descriptions of the social world as they are within that world, simultaneously affect social relations, execute moral evaluations, produce political, moral and social consequences. Descriptions almost always do much more in a social situation than simply 'reporting' a series of events "[27]. could manage, select, cut and dispose of the information collected in order to identify concepts and propositions that were articulated, illuminated and made more and more visible in the light of the various reference and theoretical frameworks that we handle. Qualitative analysis is read once and again the reality to rewrite it ${ }^{10}$ [30], in order to produce narrative constructions that account for the interpretation we make of the meanings that students give to higher education and to certain events that take place within confinement called appropriating events that come to be configured in borderline experiences. Due to its interpretative character and its situational mode, our task was directed to build dense descriptions:

"The goal is to reach great conclusions starting from small facts but very dense context, to support general enunciations on the role of culture in the construction of collective life relating it to specific and complex facts " [31].

In-depth interviews were conducted (also called in-depth interviews), understood as clues to open an open discourse [32], paths through which a dialog or "dialogical inventions" are being constructed as Arfuch calls them[33], co-productions that allow us to get closer to the meanings, beliefs or perspectives of the people with whom we are "talking" with the desire to build interpretations about interpretations.

Likewise, several observations (also called direct or participatory observations) were made in different contexts within the prisons (and even outside of them, in the customs, in the ranks of the relatives, in the PESCER offices located in one of the extramural campuses) of the University, providing "key information" that nurtured the process of qualitative analysis, the permanent elaboration of questions that guided the interviews, the codification of the data, the construction of analytical matrices and the data triangulation work.

Field as an inseparable material of the ethnographic work: invaluable source of records, explanatory notes, textualities of print, impressions or clues, all interveners of the analytical work:

"[...] key records of research and experience generated in the fieldwork. This is a resource that allows explicitly writing certain kinds of observations at the same time that it gives visibility to emotions, as feelings that unfold and become transformed in the course of research." [34]

For this research, we formed a target group of students. They accepted the invitation to participate in this work. This group was formed initially by five students, after a couple of months of work; the group was definitively

10 In this regard, Freire says that $<<$ we read and write reality to reread it and rewrite it $>>$, that is, we transform it through our conscious practice, it is "critical reflection" [30]. 
formed by Juan, El Chato and El Tío. The conformation of the target group had an intentional nature Based on criteria established at the beginning and during the first stages of research (intensive sampling, through which "key informants" are selected who have a certain authority over a particular experience and critical sampling where the central criterion was to identify certain "critical incidents" that they were significant for the construction of the object of study).

This research work took place from august 2012 to 2013. However, note that the study regarding student representations by recently released students conducted between September 2010 and July 2012 was a major precedent.

For this paper 28 conversation-interviews (in-depth, in situ interviews) were conducted with an average duration of two and a half hours with Juan, El Chato, El Tío. Furthermore, there were a large number of informal talks with inmates (students and non-students at the Norte and Oriente prisons and the Mexico City Penitentiary), with prison guards and supervisors, with family members of some inmates, and of course with those recently released.

\section{Conclusions}

Throughout the three chapters that comprise this paper we risked giving account of how a limit experience constitutes an opening to approach the being, the being that cannot easily be grasped. Thus, the question of the meaning of being guided the development of the entire research project. But, as Heidegger says, it is only possible to question one's being from the entity that is capable of questioning itself, that entity that, by questioning its sense of being must put its own meaning into play. It is the being that has no other recourse but to be, which has the possibility of posing the problem of the being in order to understand it, in order to somehow grasp it, and that is what sets it apart.

This problem-posing takes various forms. One of them occurs precisely because of a limit experience, an experience that "materializes" in certain events that allow us to appropriate something, that reveal to us the finitude on the one hand, and, on the other, the anguish, that which, upon arising, puts us face to face with nothing, that something that is the meaninglessness of life, or in other words, devoid of meaning. In understanding it is somehow shown to us that we are indebted beings, due to the fact that life has no predetermined meaning and thus, we must choose, and take on the responsibility of discovering, creating, inventing, or endowing our life with meaning. What Juan, El Chato, and El Tío make happen through speech, are certain appropriations achieved based on certain events: appropriations that give account of comprehension of the meaninglessness of life, the finitude of our existence, uncertainty as a condition, incompleteness, lack, and debt. Appropriations that place, or rather, displace ${ }^{11}$ [35] them, which allow them to project themselves toward other horizons of meaning.

The limit experience opened by the prison experience takes place there where equilibrium is broken, fractured, where anguish is made present and nothingness is made manifest, where appropriation of death is made possible, and thus authentic comprehension of finitude; the liminary experience shows us a strange, unknown, alien, delimited territory that reveals something to the extent that we inhabit it, dwell there, and it calls us to choose ourselves, it marks and transforms us upon opening us to experiencing the being in the light of the event: it's a rite of passage: "now I know something I did not know before... after that... after what happened to me I have changed, I have learned" confesses El Tío.

A limit experience is a way of opening up to the world that makes the totality of it accessible; from another perspective, it is a liberating pedagogical experience. It is opening, says Freire, it is consciousness ${ }^{12}$ [36] that, by opening up to the finitude, overcomes its own limits, its own barriers. Consciousness that seeks to add up to more than just itself, but never manages to do it, which moves toward greater consciousness, but does it in conjunction with everyone else, and which goes on allowing the inmate and the parolee to rediscover themselves as they reflexively assume their own process in which they discover themselves. It is transformative reflection or transforming action, which intersects with reality, with the everyday, establishing a different situation, giving rise to the search to be more, in the words of Freire [37].

On the other hand, we explore what it is like to return home when one has foreseen death, when the anguish has uncovered the nothingness, the meaninglessness of life, when it has been understood that all we are is the possibility of being, and that only by projecting this possibility of being will we come to "be what already is," when we have managed to distinguish the authentic from the inauthentic, even if only momentarily, when one no longer departs from the horizon of "believing that one knows it all," when one has stopped "jumping from one thing to another," getting lost and vanishing. We go inside ourselves to give account of that something that happened in prison, of that which was revealed at floor level [laying on the bathroom floor, El Tío] or in the midst of the riot [Juan], or against the clamor of the lynching, of that which made something fall into place, of that which revealed itself, giving rise to both understanding and the encounter, of that which gave singularity to the return, a particularity that sets it apart

11 Heidegger connects "[...] the experience of strangeness in the emphatic sense with displacement. In any case, such experience acquires importance for the hermeneutics of facticity or the phenomenology of living due to the face that, in this case, the displacement must be interpreted as limit experience" [35].

12 "Consciousness is comprised of the consciousness of the world [...], consciousness does not meet itself in the vacuum of itself, because consciousness is always, radically, world consciousness" [36]. 
from other returns home.

This way of returning home speaks to us of all that suffering, that pain of not being able to reach what is desired; longing for the unreachable, restlessness expressing unease due to something that is not had [and that even if one knows it will not be able to be had it is still longed for], a desire that is impossible to reach precisely because it is nostalgia: nostalgia as an expression of absence, as recognition of a distance, as an impossibility to take root. Return that expresses the absence and pain that are interwoven with encounters and estrangements, with joy, euphoria, and astonishment, with familiarity and strangeness, adaptation and "not fitting in."

We come to the resolution that that return may come to be possibility, opening, substrate for the irruption of something that places us face to face with the limit, the background where those opportune events that make something be clearly in its place thrive. This return home is a possibility not to return; it is a journey that in reality has no departure point or final destination, it is learning, possibility of transformation, willingness to question others, to interrogate oneself; it is understanding that the world is inevitably open, not as a construction but as a choice. And this for us is no small thing: "The self that opens itself to the world and to others establishes with its gesture the dialogical relationship in which it is confirmed as restlessness and curiosity, as in conclusion in constant movement in history," as stated by Freire and Faundez [38].

Willingness to question oneself, to stand in solidarity with oneself, to learn and anchor hope in transformative practice; willingness to commit oneself to one's social and cultural context, in order to recognize injustice in the everyday life and work to reverse it, to assume that all educational processes have to arise from specific problems; willingness to take part in the world and not just adapt to it, as Freire says:

"Education makes sense because the world is not necessarily this or that, because as human beings we are a project and at the same time we can have projects for the world. Education makes sense because women and men learned that they are made and remade by learning, because women and men were able to assume the role of beings that are able to know, to know that they know, and to know that they do not know. [...] Education makes sense because, in order to be, women and men need to be being" [39].

Thus, higher education--and particularly university learning in imprisonment and parole contexts - cannot depart from the illusion that supposes that adults learn what they're taught, as Arnold states. Learning in adults is not always accompanied by teaching activities or activities guided by a syllabus or plan. It is critical that those of us who teach "inside" prisons can understand this from "the internal perspective of the subject who is learning" and, from there, promote analysis, reflection, and meditative thought on patterns of interpretation and on the subject's learning projects: "adult education is an education that comes from the other" [40].

Takeaways. Some of the results of this research paper will make it possible to strengthen actions and reflections that the Higher Education Program for Centers of Social Re-adaptation in Mexico City (PESCER-UACM) carries out each year as part of its self-evaluation.

Likewise, the same results will have a bearing on the educational processes promoted by the UACM and PESCER in particular, in order to reverse the isolation and marginalization of the prison population. Said formative processes in higher education are grounded in respect for diversity and promoting democratic ways of life. By recovering the value of what is public in the broadest sense of the word, UACM:

"creates new spaces for educating, regardless of one's particular social or economic situation, gives value to the individual, the human being, their capacity to grow and to learn while encouraging freedom of thought and responsibility of decision" [41].

On the other hand, there are few experiences of on-site university education at penitentiary centers (see Díaz-Pontones and Mora Gutierrez [42]). Thus, the results will be used to contribute to understanding university education of students in confinement and parole, in promoting strategies, policies, and actions that favor school retention rates in higher education and strengthening of actions and practices between the UACM and confinement centers in order to contribute.

Another takeaway from this research paper is that it offers another look at the return home from a limit experience having occurred in confinement, and what this means in terms of learning experiences that substantially modify axiological and behavioral parameters.

Finally, we would like to note that the reflection and meditation by university students gives rise to willingness, a questioning of oneself, a questioning of others, an interrogation after something has occurred, that understanding that the world is inevitably open, not as a construction but as a choice:

"The self that opens itself to the world and to others establishes with its gesture the dialogical relationship in which it is confirmed as restlessness and curiosity, as in conclusion in constant movement in history" [43].

\section{REFERENCES}

[1] H. W. Petzet. Encuentros y diálogos con Martin Heidegger. 1929-1976, 2007, p. 229. Online available from http://books.google.com.mx/books?id=tUqoF8Xj8M4C\&d 
$\mathrm{q}=$ Encuentros $+\mathrm{y}+\mathrm{di} \% \mathrm{C} 3 \% \mathrm{~A} 1 \log \mathrm{os}+\mathrm{con}+$ Martin + Heidegge r. $+1929-1976 . \& \mathrm{hl}=$ es\&source $=$ gbs_navlinks_s

[2] L. Tamayo. Heidegger y la transmisión, Journal La lámpara de Diógenes, Revista de filosofia, Vol. 12, No. 22-23, 43-54, 2011, p.46, Conferencia presentada en el III Coloquio internacional: El carácter metódico de la fenomenología y la hermenéutica y su relación con otros saberes. Facultad de Filosofia y Letras, BUAP. Online available from http://www.ldiogenes.buap.mx/revistas/22/43.pdf

[3] A. Constante. La metáfora de las cosas (Nietzsche, Heidegger, Rilke, Freud), Arlequín-Sigma Servicios Editoriales, México, 2003, p. 63.

[4] L. Tamayo. Del síntoma al acto. Reflexiones sobre los fundamentos del psicoanálisis, Universidad Autónoma de Querétaro, México, 2001, p.27, Footnote 6.

[5] J-L. Nancy. La comunidad inoperante, Universidad ARCIS, LOM Ediciones, Santiago de Chile: Escuela de Filosofía, 2000, p. 37. Online available from:

http://www.lacomunitatinconfessable.cat/wp-content/uploa ds/2009/10/18223929-la-comunidad-inoperante-jeanluc-na ncy.pdf

[6] UACM, UACM Web Page, 2017. Online available from http://www.uacm.edu.mx/nuestrauni/index.html

[7] UACM-PESCER, Web Page, 2017. Antecedentes. Online available from:

https://portalweb.uacm.edu.mx/uacm/pescer/es-es/antecede ntes.aspx

[8] E. Goffman. Internados, Amorrortu, Buenos Aires, 2004, p. 60.

[9] CLADE. Educación en contextos de encierro ¡Derecho humano inalienable! Campaña Latinoamericana por el derecho a la educación, Brasil, 2011, pp.16-17. Online available from: www.campanaderechoeducacion.org

[10] F. Scarfó. La educación pública en los establecimientos penitenciarios en Latinoamérica: Garantías de una igualdad sustantiva. En Organización de las Naciones Unidas para la Educación, la Ciencia y la Cultura UNESCO (2008). Educación en prisiones en Latinoamérica. Derechos, libertad y ciudadania, UNESCO-OEI-AECID, Brasilia, 2008, p. 116.

[11] A. Constante. El oscuro humus de la tierra. En R. Guerra. A. Yáñez (Coordinadores). Martín Heidegger. Caminos, (Pp. 33-40), UNAM, México, 2009.

[12] L. Tamayo. Del síntoma al acto. Reflexiones sobre los fundamentos del psicoanálisis, Universidad Autónoma de Querétaro, México, 2001, p.27 Footnote 6.

[13] L. Tamayo. Cotidianidad y caída. Journal Intersticios, Universidad Intercontinental, año 16, No. 35, 45-53, 2011, pp.49-50.

[14] M. Heidegger. El ser y el tiempo, FCE, México, 1971, p. 46.

[15] P. Ariès. Morir en Occidente, desde la edad media hasta la actualidad, Adriana Hidalgo Editora, Buenos Aires, 2007, p.72.

[16] L. Tamayo. La locura ecocida. Ecosofía psicoanalítica, Fontamara-CIDHEM, México, 2010, p. 65.
[17] L. Tamayo. La locura ecocida. Ecosofía psicoanalítica, Fontamara-CIDHEM, México, 2010, p. 66.

[18] A. Dartigues. La fenomenología, Herder, Barcelona, 1981, p. 147.

[19] P. Redondo. Heidegger ante la fenomenología de Husserl, 1999 , p. 120. Online available from: www.uma.es/contrastes/pdfs/004/Contrastes004-09.pdf

[20] M. Heidegger. Los conceptos fundamentales de la metafísica. Mundo, finitud y soledad, Alianza Editorial, Madrid, 2007, p. 29.

[21] A. Rocha de la Torre. Retorno al hogar y reconocimiento del otro en la filosofía de Martín Heidegger, Acta fenomenológica latinoamericana, III, 659-672, Actas del IV Coloquio Latinoamericano de fenomenología, Círculo Latinoamericano de Fenomenología, Lima, Perú, P.U.C. de Perú-Morelia, México, Universidad Michoacana de San Nicolás de Hidalgo, 2009, p. 660.

[22] A. Yáñez. Heidegger y Hölderlin. Recuerdo, tiempo y nostalgia, En: CIDHEM, Metafísica y Ontología. Homenaje al Dr. Ricardo Guerra, Centro de Investigación y Docencia en Humanidades del Estado de Morelos, CIDHEM, México, 2005, p. 121.

[23] J-L. Nancy. La existencia exiliada. Jornal Archipiélago. Cuadernos de crítica de la cultura, No. 26-27, 1996, p. 39.

[24] L. Tamayo. La locura ecocida. Ecosofía psicoanalítica, Fontamara-CIDHEM, México, 2010, p. 66.

[25] J. Derrida. Cierta posibilidad imposible de decir el acontecimiento (Palabras en el Seminario: $<<$ Decir el acontecimiento ¿es posible? $>>$, Realizado en el Centro Canadiense de Arquitectura), Derrida en castellano, 1977, p. 1. Online available from:

http://www.egs.edu/faculty/jacques-derrida/articles/cierta-p osibilidad-imposible-de-decir-el-acontecimiento/

[26] M. Beuchot. Hermenéutica analógica y ontología, CIDHEM, México, 2013,p. 72.

[27] H. Schwartz y J. Jacobs. Sociología cualitativa. Métodos para la reconstrucción de la realidad, Trillas, México, 1996, p. 79.

[28] P. Willis. Sobre el rol de la Teoría, En, Notes on Method. En Hall, S. et al. (eds.) (1980). Culture, Media, Language, (Pp. 88-95), Hutchinson, Londres, 1980, p. 4. Online available from:

https://es.scribd.com/document/110726160/Willis-Notas-so bre-metodo

[29] C. Geertz. Estar allí: la antropología y la escena de la escritura, En: El antropólogo como autor, (Pp. 11-34), Paidós, Barcelona, 1989.

[30] P. Freire. La importancia del acto de leer y el proceso de liberación, Siglo XXI, México 2004, p.18.

[31] C. Geertz. Descripción densa: hacia una teoría interpretativa de la cultura. En: La interpretación de las culturas, (Pp. 17-40), Gedisa, Barcelona, 2003, p. 38.

[32] J.P. Goetz y M. LeCompte. Etnografía y diseño cualitativo en investigación educativa, Morata, España, 1988. 
[33] L. Arfuch. La entrevista, una invención dialógica, (P. 27-32), Paidós, Barcelona, 1995, p. 30.

[34] A.R. Ameigeiras. El abordaje etnográfico en la investigación social. En I. Vasilachis de Gialdino (Coordinadora). Estrategias de investigación cualitativa, (Pp. 107-151), Gedisa, España, 2006, p. 136.

[35] H-H. Gander. La fenomenología hermenéutica del vivir fáctico de Heidegger. En: F. Duque, (Ed.), Heidegger sendas que vienen, Volumen 1, (Pp. 139-171), Círculo de Bellas Artes, España, 2008, p. 156.

[36] E. Fiord. Aprender a decir su palabra. El método de alfabetización del profesor Paulo Freire, En: P. Freire. Pedagogía del oprimido, (Pp. 3-20), Siglo XXI, México, 1973, p. 12.

[37] P. Freire. Pedagogía del oprimido, Siglo XXI, México, 1973, p. 104.

[38] P. Freire y A. Faundez. Por una pedagogía de la pregunta: crítica a una educación basada en respuestas a preguntas inexistentes, Siglo XXI, Argentina, 2013, p. 9.

[39] P. Freire. Pedagogía de la indignación: cartas pedagógicas en un mundo revuelto, Siglo XXI, Buenos Aires, 2012, p. 47.

[40] R. Arnold. La educación de adultos como trato con lo ajeno. Desde la creación hasta la transformación de patrones de interpretación, En: U. Klesing-Rempel. Lo propio y lo ajeno. Interculturalidad y sociedad multicultural, (Pp. 277-299), Plaza y Valdés-Asociación Alemana para la Educación de Adultos-Instituto de la Cooperación Internacional, México, 1996, p. 293.

[41] UACM. UACM Web Page, 2009. Online available from: http://www.uacm.edu.mx/nuestrauni/index.html

[42] M. Díaz Pontones y L. A. Mora Gutiérrez. Significados, creencias, percepciones y expectativas de la formación universitaria de los estudiantes en situación de reclusión: informe de investigación, UACM-PESCER, México, 2009.

[43] P. Freire y A. Faundez. Por una pedagogía de la pregunta: crítica a una educación basada en respuestas a preguntas inexistentes, Siglo XXI, Argentina, 2013, p. 9. 